${ }^{\bullet}$ Entomologica Fennica. 22 October 2001

\title{
Natural history of some Siberian melitaeine butterfly species (Nymphalidae: Melitaeini) and their parasitoids
}

\author{
Niklas Wahlberg, Jaakko Kullberg \& Ilkka Hanski
}

\begin{abstract}
Wahlberg, N., Kullberg, J. \& Hanski, I. 2001: Natural history of some Siberian melitaeine butterfly species (Nymphalidae: Melitaeini) and their parasitoids. — Entomol. Fennica 12: 72-77.

We report observations on the larval gregarious behaviour, host plant use and parasitoids of six species of melitaeine butterfly in the Russian Republic of Buryatia. We observed post-diapause larvae in two habitats, steppe and taiga forest region. Five species were found in the steppe region: Euphydryas aurinia davidi, Melitaea cinxia, M. latonigena, M. didymoides and M. phoebe. Three species (M. cinxia, $M$. latonigena and $M$. didymoides) fed on the same host plant, Veronica incana (Plantaginaceae). Euphydryas aurinia larvae were found on Scabiosa comosa (Dipsacaceae) and M. phoebe larvae on Stemmacantha uniflora (Asteraceae). Three species were found in the taiga region (M. cinxia, M. latonigena and M. centralasiae), of which the first two fed on Veronica incana. Five species of hymenopteran parasitoids and three species of dipteran parasitoids were reared from the butterfly larvae of five species.
\end{abstract}

Niklas Wahlberg, Department of Zoology, Stockholm University, S-106 91 Stockholm, Sweden; E-mail:niklas.wahlberg@zoologi.su.se Ilkka Hanski, Metapopulation Research Group, Department of Ecology and Systematics, Division of Population Biology, P.O. Box 17, FIN-00014 University of Helsinki, Finland; E-mail: ilkka.hanski@helsinki.fi Jaakko Kullberg, Finnish Museum of Natural History, P.O. Box 17, FIN00014 University of Helsinki, Finland; E-mail: jaakko.kullberg@helsinki.fi

Received 2 February 2001, accepted 18 April 2001

\section{Introduction}

Butterflies belonging to the tribe Melitaeini have been much studied during the past few decades (Ehrlich et al. 1975, Bowers 1983, Warren 1987, Thomas \& Singer 1998, Hanski 1999). These studies have taken place in North America and Europe, while virtually nothing is known about the ecology of the eastern Palaearctic species. Palaearctic melitaeines belong to two genera, Melitaea (including Mellicta) with about 55 species and
Euphydryas with 8 species (Higgins 1981). We follow Wahlberg and Zimmermann (2000) for the generic classification of melitaeine butterflies and Judd et al. (1999) for the familial classification of plants.

The biology of all species of Melitaeini is broadly similar. With no known exception, melitaeines lay their eggs in batches, with the species-specific average batch size varying from about 20, e.g. Melitaea didyma (Esper, 1779) (Vogel 1996), to over 200, e.g. Euphydryas 
aurinia (Rottemburg, 1775) (Wahlberg 2000). Larvae often live gregariously during the early instars, though the degree of gregariousness of larvae varies. It appears that the degree of gregariousness is positively correlated with the average size of the egg batch, i.e. species laying small egg batches have larvae that are not very gregarious, while species laying large egg batches have very gregarious larvae. Even in the highly gregarious species, groups tend to break up during the later larval stages. The evolutionary significance of the putative correlation between larval gregariousness and egg batch size needs to be investigated in a more rigorous fashion, but such a study requires observations from more melitaeine species. All species diapause as mid-instar larvae, and usually the fourth instar is the diapausing instar. Some species are known to diapause in groups within tightly woven winter webs, e.g. Melitaea cinxia and Euphydryas aurinia, while others diapause individually inside dried up curled leaves, e.g. Melitaea athalia (Rottemburg, 1775).

Host plants of Melitaea species in Europe commonly belong to the families Plantaginaceae and Orobanchaceae with some species specializing on plants in the Asteraceae (Wahlberg 2001). Euphydryas species are found on a wider variety of host plants, belonging to the families Plantaginaceae, Orobanchaceae, Caprifoliaceae, Dipsacaceae and Oleaceae (Wahlberg 2001). However, most Euphydryas species are at most oligophagous at the population level (Singer 1983). All the plant families mentioned above except Asteraceae are united by the presence of a class of plant secondary compounds known as iridoids (Jensen et al. 1975). It has been shown that iridoids have had a substantial impact on the evolution of host plant use in melitaeines (Wahlberg 2001).

In this paper we describe observations on the natural history and parasitoids of 6 species of melitaeines found in southern Siberia during spring 1998. We compare our observations to the known life histories of related species in Europe.

\section{Material and methods}

We searched for post-diapause melitaeine larvae during the spring of 1998 in the Republic of Buryatia, Russia. We searched for larvae in two types of habitat, the dry steppe close to the city of Ulan Ude (28 April to 1 May and 7 May to 14 May) and moist meadows in the taiga zone about 500 $\mathrm{km} \mathrm{N}$ of Ulan Ude in the Barguzin Valley (2 May to 6 May). All larvae that were found were collected and reared in plastic containers. Any parasitoids emerging from the larvae were collected for identification. We attempted to identify the host plant of the larvae, though this was not always possible.

The larvae were brought back to Finland to be reared to the adult stage. We also brought back enough of the relevant host plant so that the larvae could complete development on their natural host plants. The larvae were segregated according to morphological differences, mainly in colour patterns. We were able to identify larvae of three species already in the field, namely those of Melitaea cinxia, Melitaea phoebe and Euphydryas aurinia. The other species were identified as adults or, in the case of $M$. centralasiae that died as larvae, based on a $640 \mathrm{bp}$ sequence of the cytochrome oxidase subunit 1 in the mitochondrial DNA (Wahlberg \& Zimmermann 2000; GenBank Accession number AF187751).

The rearing of one species (Melitaea didymoides) was continued past the adult stage. One mating was obtained and the female was given natural host plants for oviposition. The subsequent egg batches were collected and the hatching larvae were reared to diapause on their natural host plant. We recorded the behaviour of young larvae.

We conducted a small number of experiments on parasitism with the material collected in Buryatia. Female wasps of Cotesia melitaearum that emerged from Melitaea cinxia were offered 4th to 6th instar larvae of different species to parasitize, their behaviour was observed and the host larvae were reared. Larvae were offered to wasps in small plastic containers, under conditions in which Finnish $C$. mealitaearum readily parasitize full-grown larvae of $M$. cinxia (pers. obs.).

\section{Results}

We collected a total of 939 larvae belonging to 6 species (Table 1). Three species were found only in the steppe region, one species only in the taiga region and two species were found in both areas (Table 1). The post-diapause larvae of four species, E. aurinia, M. didymoides, M. latonigena and $M$. centralasiae, were found to be solitary. We found these larvae in the 4th, 5th and 6th instars. Two species, M. phoebe and M. cinxia, were found in groups. The larvae of $M$. phoebe were found in small groups of 5 to 10 larvae per host plant.

Melitae a cinxia larvae in the taiga region were at an earlier stage of development, and they were found in larger groups than the conspecific larvae 
in the steppe region. Remains of larval webs were clearly visible in the close vicinity of the larval groups in the taiga populations, while in the steppe populations we found only old webs some distance from the larvae. Thus, the larvae in the steppe had largely dispersed and most were in their last instar.

Three species used the same host plant species: Veronica incana (Plantaginaceae) (Table 1), which was very abundant in both regions. Euphydryas aurinia larvae were found on Scabiosa comosa (Dipsacaceae) and the larvae of Melitaea phoebe were found on Stemmacantha uniflora (Asteraceae). Larvae of these two latter species did not accept Veronica incana in rearings. The two M. centralasiae larvae were found as 4th instar larvae that had apparently just broken diapause. These larvae fed sparingly on Veronica incana in rearing but did not grow. They eventually died after two months at essentially the same size as when they were found. The larvae were identified to species using molecular markers isolated from adults collected earlier in the same area (Wahlberg \& Zimmermann 2000).

The habitat of melitaeines in the steppe area was mainly on the southern slopes of hills. We were unable to find larvae on the northern slopes, which were cooler and received less sunshine. The habitat was rich in herbs, of which species such as Pulsatilla spp., Potentilla acaulis and Veronica incana were most visible in the early spring. Larvae were found most often in areas with very low vegetation and patches of bare ground. There was no evidence that these patches would be overgrown by grasses later on in the season.

The habitat in the taiga region was moist meadow with apparently rather tall vegetation during the summer (ca. $30 \mathrm{~cm}$ ), judged by the dead stalks of plants of the previous year. Larvae were found in patches of lower vegetation with plenty of $V$. incana. The two $M$. centralasiae larvae were found in the same area as the larvae of $M$. latonigena. When found, they were considered to be feeding on $V$. incana, but this assumption turned out to be wrong. All $M$. cinxia larvae were found in an abandoned field that was overgrown with $V$. incana.

The mated $M$. didymoides female laid three egg batches of 8,11 and 14 eggs. The eggs were rather large in size compared to those of $M$. cinxia (N. Wahlberg pers. obs.), which lays many more eggs per batch (Kuussaari 1998). Upon hatching the larvae did not behave gregariously at any stage. The larvae also did not spin any web, unlike the larvae of many melitaeines (Wahlberg 2000). The larvae fed solitarily until diapause. First instar larvae fed underneath the host plant leaf leaving a thin film uneaten.

We reared 5 species of hymenopteran and 3 species of dipteran parasitoids from 5 host species (Table 2). The braconid wasp Cotesia melitaearum was reared from $M$. cinxia and $E$. aurinia, which are well-known hosts from Europe (Komonen 1998). Cotesia acuminatus was reared from $M$. latonigena and $M$. phoebe. The former host record appears to be new. These identifications are based on extensive comparisons with European material by Dr. M. Shaw, but still leave open the possibility that several very closely related taxa could be involved. Molecular work on these taxa will provide additional information about their taxonomic status (M. Kankare unpubl.). The ichneumonid species (Table 2) could not be reliably identified to species

Table 1. The species of melitaeines found as post-diapause larvae in the spring in the Russian Republic of Buryatia in the spring 1998.

\begin{tabular}{lclll}
\hline Species & $\begin{array}{c}\text { Larvae } \\
\text { sampled }\end{array}$ & Host plant & Habitat & $\begin{array}{l}\text { Larval } \\
\text { behaviour }\end{array}$ \\
\hline Euphydryas aurinia davidi & 12 & Scabiosa comosa & Steppe & Solitary \\
Melitaea cinxia (L., 1758) & 581 & Veronica incana & Both & Group \\
Melitaea latonigena Eversmann, 1847 & 89 & Veronica incana & Both & Solitary \\
Melitaea didymoides Eversmann, 1847 & 193 & Veronica incana & Steppe & Solitary \\
Melitaea phoebe (Denis \& Schiffermüller, 1775) & 62 & Stemmacantha uniflora & Steppe & Group \\
Melitaea centralasiae (Wnukowsky, 1929) & 2 & $?$ & Taiga & Solitary \\
\hline
\end{tabular}


due to very limited material. The possible species are Benjaminia horstmanni Wahl, 1989, Hyposoter horticola (Gravenhorst) (known from M. cinxia in Europe) (Lei et al. 1997) and Ichneumon gracilicornis Gravenhorst (Dr. M. Shaw pers. comm.).

The 3 tachinid species were reared from 3 host species (Table 2). Erycia species are well known parasitoids of Melitaea and Euphydryas. Nemorilla maculosa has not been previously reared from Melitaea (Dr. H.-P. Tschorsnig pers. comm.). The specimen reared from $M$. didymoides came out from a larva, whereas the Erycia larvae came out of pupae. Erycia festinans was very common in M. cinxia in the taiga region (Djirga) but it was not reared from the steppe region. Melitaea latonigena is a new host for Erycia fasciata.

In the experiments on parasitism, larvae of the following species from Buryatia and Finland were offered to Cotesia melitaearum that had been reared from post-diapause Melitaea cinxia larvae collected in Buryatia: Melitaea cinxia (7 experiments), $M$. didymoides (4 experiments), $M$. latonigena (4 experiments), M. phoebe (1 experiment), $M$. athalia (Finnish material, 3 experiments), and Euphydryas maturna (3 experiments). The female wasps showed no interest to oviposit any of the larvae of M. athalia and E. maturna, and they appeared to oviposit only 2 of the $4 M$. didymoides and 1 of the $4 M$. latonigena larvae. Eventually, wasp progeny emerged only from 5 of the $7 \mathrm{M}$. cinxia larvae used in the experiments. These results support the observational results on the host use of Cotesia melitaearum in Buryatia (Table 2).

\section{Discussion}

We were able to make detailed observations on the post-diapause larvae of six species. The biology of $M$. cinxia and M. phoebe differ from their European counterparts only in the host plant species used (Tolman \& Lewington 1997, Kuussaari 1998). Most M. cinxia populations in Europe use Plantago lanceolata as their host plant, with some central and northern European populations using a few Veronica species (V. spicata, $V$. teucrium) in addition to $P$. lanceolata. We did not find any Plantago species in the habitats we investigated in Buryatia, and it is likely that M. cinxia is monophagous on $V$. incana in Buryatia. Veronica incana is very similar in growth form to $V$. spicata, an important host plant in Finland and Estonia, and indeed is sometimes considered to be conspecific with the latter.

In Europe, Euphydryas aurinia aurinia is known for its gregarious larval behaviour in the spring (Porter 1982, Klemetti \& Wahlberg 1997). Our observations on the larvae of E. aurinia davidi indicate that they are more solitary in nature. All larvae were found singly though sometimes with 2 or 3 other individuals within a few meters. This suggests the possibility that $E$. a. davidi lay eggs in smaller batches than E. a. aurinia, as has been recorded for a related species $E$. desfontainii (Thomas \& Mallorie 1985). The host plant of E. $a$. davidi is a small herb and would not be able to support a large group of larvae in the autumn.

Two species for which there was no previous information about the larval stages (M. didymoides and $M$. latonigena) are both closely related to $M$. didyma of the western Palaearctic region (Higgins

Table 2. The species of parasitoids reared from the melitaeine larvae found in the Russian Republic of Buryatia.

\begin{tabular}{llll}
\hline Species & Order & Habitat & Host \\
\hline Cotesia melitaearum (Wilkinson, 1937) & Hymenoptera & Both & M cinxia, E. aurinia \\
Cotesia acuminatus (Reinhard, 1880) & Hymenoptera & Steppe & M. phoebe, M. latonigena \\
Benjamina sp. & Hymenoptera & Steppe & M. didymoides \\
Hyposoter sp. & Hymenoptera & Steppe & M. phoebe \\
lchneumon sp. & Hymenoptera & Steppe & M. cinxia \\
Erycia festinans (Meigen, 1824) & Diptera & Taiga & M. cinxia \\
Erycia fasciata (Villeneuve, 1924) & Diptera & Taiga & M. latonigena \\
Nemorilla maculosa (Meigen, 1824) & Diptera & Steppe & M. didymoides \\
\hline
\end{tabular}


1981). The general colouration of the late instar larvae was similar to that of M. didyma. Larvae of $M$. didymoides were lighter in colour than $M$. latonigena, which were almost identical to larvae of M. didyma (NW pers. obs.) Also the larval behaviour of these two species was much like the behaviour of $M$. didyma larvae in the spring (Vogel 1996, Komonen 1998), i.e. the larvae fed solitarily and did not bask in groups.

The unwillingness of the M. centralasiae larvae to feed on $V$. incana is surprising in view of the close relationship of this species to Melitaea aurelia (Nickerl, 1850) (Wahlberg \& Zimmermann 2000). Melitaea aurelia is known to feed on Plantago lanceolata (Tolman \& Lewington 1997 ) and P. media (in Estonia, S. van Nouhuys, pers. comm.), and several melitaeine species are known to feed on Plantago and Veronica, indicating that species in these two plant genera tend to be biochemically similar (Wahlberg 2001). On the other hand, another species belonging to the same clade as M. centralasiae (Wahlberg \& Zimmermann 2000), M. varia (Meyer-Dür, 1851), is known to feed on a species belonging to Gentianaceae (Tolman \& Lewington 1997), which is biochemically different to the previous genera (see Jensen et al. 1975). It appears that $M$. centralasiae feeds on a plant species that is biochemically different to $V$. incana.

The egg-laying behaviour and pre-diapause larval behaviour of $M$. didymoides reflected the close relationship to $M$. didyma. The number of eggs per batch (about 10) is very small compared to other species of Melitaea. For instance, $M$. cinxia has on average 170 eggs per batch (Kuussaari 1998), M. diamina (Lang, 1789) has 100 eggs per batch (Wahlberg 1997) and M. athalia has about 50 eggs per batch (Warren 1987). On the other hand, M. didyma is known to lay small egg batches of 10 to 20 eggs per batch (Vogel 1996). Small egg batch size may be a characteristic of the entire species group, which includes about 20 species (Higgins 1981).

The results on parasitoids revealed some noteworthy patterns. First, only a single species of Cotesia was reared from each of four host species, in agreement with the general observation that it is unusual for one melitaeine host to have two syntopic Cotesia (Komonen 1998). Second, all the 6 solitary parasitoids reared from this mate- rial (Table 2) emerged from just one host species. All these parasitoids apart from Erycia festinans from Melitaea cinxia were uncommon, however, which may explain the restricted host ranges. Interestingly, the latter species as well as E. fasciata from $M$. latonigena were reared only from the taiga forest region, while an ichneumonid species parasitized $M$. cinxia in the steppe region. Finally, there was no indication that the host plant species would particularly influence the host associations in these parasitoid species. Seven parasitoids were reared from hosts on Veronica incana, whereas the two Cotesia species were each reared from two host species on two different plant species (Table 2).

In summary, the ecology of the five species of melitaeines for which we were able to make detailed observations did not differ much from the ecology of European conspecifics or related species. This is not surprising as the melitaeines are a relatively young group of butterflies (Wahlberg \& Zimmermann 2000) and the ecological requirements of closely related species are expected to be similar. The host plant species utilized by the melitaeines differed from their European counterparts, though the host plants belonged to the same plant families. The life histories of the larvae were also generally similar, with the exception of E. aurinia davidi with larvae less gregarious than those of the European E. aurinia aurinia.

Acknowledgements. We thank our hosts and guides in Buryatia: Sergei Danilov, Sergei Rudykh and Tatyana (whose last name we unfortunately are unable to find out due to communication problems). This work was done in cooperation with the Buryatian Institute of Natural Sciences. We also thank Janne Heliölä, Zdravko Kolev and Vesa Selonen for help in the field, and M. Shaw and H.-P. Torschnig for identifying the parasitoids. Permissions to import and export live larvae were granted by Kasvintuotannon Tarkastuskeskus, Helsinki and Ministry for Agriculture, Ulan-Ude, respectively. NW thanks Matti Koivula for taking over the editorial duties.

\section{References}

Bowers, M. D. 1983: The role of iridoid glycosides in hostplant specificity of checkerspot butterflies. - J. Chem. Ecol. 9: 475-493.

Ehrlich, P. R., White, R. R., Singer, M. C., McKechnie, S. W. \& Gilbert, L. E. 1975: Checkerspot butterflies: a 
historical perspective. - Science 188: 221-228.

Hanski, I. 1999: Metapopulation Ecology. — Oxford University Press, Oxford. 313 pp.

Higgins, L. G. 1981: A revision of Phyciodes Hübner and related genera, with a review of the classification of the Melitaeinae (Lepidoptera: Nymphalidae). — Bull. Brit. Mus. Nat. Hist. 43: 77-243.

Jensen, S. R., Nielsen, B. J. \& Dahlgren, R. 1975: Iridoid compounds, their occurrence and systematic importance in the angiosperms. - Bot. Notiser 128: 148-180.

Judd, W. S., Campbell, C. S., Kellogg, E. A. \& Stevens, P. F. 1999: Plant Systematics: A Phylogenetic Approach. - Sinauer Associates, Sunderland, MA. 410 pp.

Klemetti, T. \& Wahlberg, N. 1997: The ecology and population structure of the marsh fritillary (Euphydryas aurinia) in Finland. — Baptria 22: 87-93. [In Finnish with English summary] .

Komonen, A. 1998: Host species use in parasitoids of Melitaeini butterflies in southern France. - Baptria 23: 194-200. [In Finnish with English abstract] .

Kuussaari, M. 1998: Biology of the Glanville Fritillary Butterfly (Melitaea cinxia). — Ph. D. thesis, University of Helsinki. 149 pp.

Lei, G. C., Vikberg, V., Nieminen, M. \& Kuussaari, M. 1997: The parasitoid complex attacking Finnish populations of the Glanville fritillary Melitaea cinxia (Lep: Nymphalidae), an endangered butterfly. - J. Nat. Hist. 31: 635-648.

Porter, K. 1982: Basking behaviour in larvae of the butterfly Euphydryas aurinia. - Oikos 38: 308-312.

Singer, M. C. 1983: Determinants of multiple host use by a phytophagous insect population. _ Evolution 37: 389_
403.

Thomas, C. D. \& Mallorie, H. C. 1985: Oviposition records and larval food plants of butterflies in the Atlas Mountains of Morocco. - J. Res. Lepid. 24: 76-79.

Thomas, C. D. \& Singer, M. C. 1998: Scale-dependent evolution of specialization in a checkerspot butterfly: from individuals to metapopulations and ecotypes. - In: Mopper, S. \& Strauss, S. Y. (eds.), Genetic Structure and Local Adaptation in Natural Insect Populations. Chapman \& Hall, New York, NY, pp. 343-374.

Tolman, T. \& Lewington, R. 1997: Butterflies of Britain and Europe. - Harper-Collins Publishers, London. 320 pp.

Vogel, K. 1996: Zur Verbeitung, Populationsökologie und Mobilitat von Melitaea didyma (Esper, 1779) im Raum Hammelburg, Unterfranken. - Oedippus 13: 1-26.

Wahlberg, N. 1997: The life history and ecology of Melitaea diamina (Nymphalidae) in Finland. — Nota lepid. 20: 70-81.

Wahlberg, N. 2000: Comparative descriptions of the immature stages and ecology of the Finnish melitaeine butterfly species (Lepidoptera: Nymphalidae). Entomol. Fenn. 11: 167-174.

Wahlberg, N. 2001: The phylogenetics and biochemistry of host plant specialization in melitaeine butterflies (Lepidoptera: Nymphalidae). — Evolution 55: 522-537.

Wahlberg, N. \& Zimmermann, M. 2000: Pattern of phylogenetic relationships among members of the tribe Melitaeini (Lepidoptera: Nymphalidae) inferred from mtDNA sequences. - Cladistics 16: 347-363.

Warren, M. S. 1987: The ecology and conservation of the heath fritillary butterfly, Mellicta athalia. I. Host selection and phenology. - J. Appl. Ecol. 24: 467-482. 